\title{
Geochemistry of the Upper Paraná River floodplain: study of the Garças Pond and Patos Pond
}

\author{
Marcelo Bevilacqua Remor • Silvio Cesar Sampaio • \\ Sandra Regina Damatto - Zuleica Carmem Castilhos • \\ José Cândido Stevaux • Marcio Antônio Vilas Boas • \\ Ralpho Rinaldo dos Reis
}

Received: 10 October 2014/Published online: 17 March 2015

(C) Akadémiai Kiadó, Budapest, Hungary 2015 activities. Patos Pond is affected by sugarcane burning, gold mining, agriculture and urbanization.

Keywords Heavy metals ${ }^{210} \mathrm{~Pb} \cdot$ Lacustrine sediment . Paleolimnology

\section{Introduction}

The drainage basin of the Paraná River is the third largest in Brazil. It occupies approximately $10 \%$ of Brazil and extends into the states of São Paulo, Paraná, Mato Grosso do Sul, Minas Gerais, Goiás, Santa Catarina and the Federal District. The basin contains $32 \%$ of the country's population and $30 \%$ of the water demand but provides only $7 \%$ of the nation's available water supply. The primary sources of water quality degradation in the Paraná River basin are domestic sewage, of which only $44 \%$ undergoes treatment before disposal in the watersheds [1]; improper disposal of solid waste; industrial pollution, particularly in headwaters such as the Upper Tietê River, which is home to $40 \%$ of the industrial facilities in the country, and in the Piracicaba River basin, which is the location of the second largest industrial center in the country and the largest steel complex in Latin America; deforestation and improper soil management caused by agricultural activities; and hydroelectric power production. $60 \%$ of the electrical power capacity of the nation is located in this drainage basin, much of which is supplied by the Itaipu Hydroelectric Plant, although there are 27 other hydroelectric plants in operation in the Upper Paraná River basin [2].

The area is located between the reservoirs of the Porto Primavera Hydroelectric Plant and the Itaipu Hydroelectric Plant in Guaíra $\left(22^{\circ} 32^{\prime} \mathrm{S}-22^{\circ} 59^{\prime} \mathrm{S}\right.$ and $\left.53^{\circ} 08^{\prime} \mathrm{W}-53^{\circ} 40^{\prime} \mathrm{W}\right)$ 
at an elevation of $250 \mathrm{~m} \mathrm{[3]} \mathrm{(Fig.} \mathrm{1).} \mathrm{The} \mathrm{study} \mathrm{reach} \mathrm{has}$ been described as the last stretch of the Paraná River in Brazilian territory and has an ecosystem dominated by river-floodplain interactions $[4,5]$.

Because of its unique features, this reach of the Upper Paraná River floodplain has been the subject of many studies since 1980. These studies have focused on ecologic and taxonomic aspects including the various communities of phytoplankton [6, 7], zooplankton [8], periphyton $[9,10]$, benthic macroinvertebrates [11, 12], ichthyofauna $[13,14]$, aquatic macrophytes $[15,16]$ and birds $[17,18]$ and on the geomorphologic $[19,20]$ and hydrologic aspects of the area [21].

According to Thomaz et al. [22], the Upper Paraná River floodplain contains a wide variety of habitats and a great diversity of terrestrial and aquatic species and has a flood pulse that is believed to exert primary control on the community structure and functioning of the ecosystem. Although strongly altered by the operation of the hydroelectric plant reservoirs upstream [20], the hydrosedimentologic cycles are still affected by the climate phenomenon of the El Niño-Southern Oscillation (ENSO), which increases precipitation in the drainage basin of the Upper Paraná River floodplain [23, 24]. The Upper Paraná River floodplain is characterized by annual flood pulses that are concentrated in the summer. The magnitude of the flood pulses is correlated with the amount of suspended matter. Stronger flood pulses result in more particles being carried into the river channel and adjacent systems, which leads to an increased sedimentation rate and increased input of nutrients and contaminants [20].

Studies have been performed in this area with the goal of assessing the concentration of chemical elements in the surface sediments $[25,26]$. These studies document conditions spanning 3 years and may be considered short-term studies. Reference (background) values and an understanding of the supply of chemical elements resulting from the evolution of anthropic activities in the drainage basin have been obtained using geochronologic techniques. Among these techniques, measurements of the natural radionuclide ${ }^{210} \mathrm{~Pb}$ were important for dating recent deposits, i.e., those as much as 100 years old [27, 28].

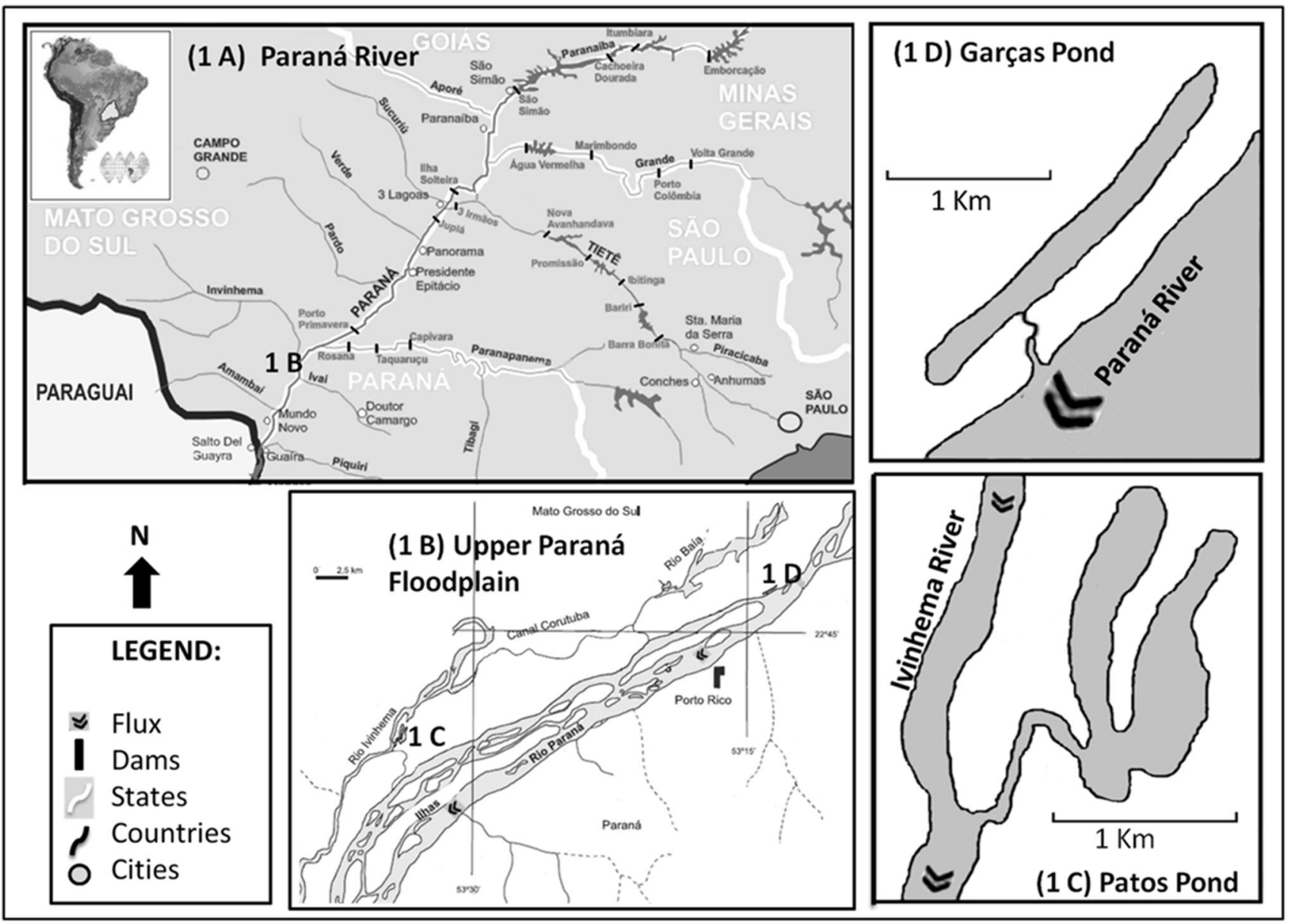

Fig. 1 Location of the study area. 1 A: Drainage basin of the Upper Paraná River; 1 B: The study reach floodplain is defined by the Paraná, Baia and Lower Ivinhema rivers.; 1 D: Garças Pond; 1 C: Patos Pond 
The radionuclide ${ }^{210} \mathrm{~Pb}$ has been used in studies of the sedimentation dynamics, nutrient supply and environments contaminants in lakes [29, 30], seas [31, 32], estuaries [33] and floodplains $[34,35]$. The method of calculating the age of a sediment as a function of its depth depends of the sedimentation model of the study area. The constant initial concentration (CIC) method is recommended in environments where the atmospheric and sediment ${ }^{210} \mathrm{~Pb}$ fluxes are constant; the constant rate of supply (CRS) method is recommended in environments where the atmospheric ${ }^{210} \mathrm{~Pb}$ flux is constant but the sediment supply is not; the constant initial reach clay activity, unknown sedimentation (CIRCAUS) model is used in heterogeneous environments where the other methods do not apply [36].

In floodplains, the sedimentation rate regulates the accumulation of nutrients, and contaminants are associated with the sediments in environments that are seasonally flooded by flood pulses. The enrichment in surface sediments and potential remobilization of chemicals to the system are known consequences of this phenomenon [37-39]. Floodplains are unique systems that differ from one another in terms of their climates and geomorphologic and anthropogenic features.

This study fills a gap in knowledge regarding the geochemistry of recent sedimentary records in the Upper Paraná River floodplain and temporal variability in the supply of chemical elements. The aim of the study was to investigate the temporal evolution of the concentrations of chemical elements in the sediment and to identify historical trends in the drainage basin of the Upper Paraná River floodplain.

\section{Experimental}

\section{Study area}

According to Stevaux et al. [20] $811 \mathrm{~km}$ of the Paraná River is located in Brazil, the stretch corresponding to the Upper Paraná River floodplain flows in its natural channel for a distance of only $200 \mathrm{~km}$. The climate of the Upper Paraná River floodplain is classified as Cfa in the Köppen system, i.e., tropical-subtropical; the average annual temperature is $22{ }^{\circ} \mathrm{C}$, and the average annual rainfall is $1,500 \mathrm{~mm}$. The native vegetation of the region is seasonal semideciduous forest, which has been reduced to small fragments near the Paraná River and its islands. The floodplain landscape is a complex mosaic that includes forest remnants, stretches of riparian forest, swamp forests, buriti orchards, shrub vegetation, grasslands and wetlands. In addition to the segments of large rivers such as the Paraná, Ivinhema and Baía, there are floodplain lakes, secondary channels, more than 100 islands and sandy and marshy beaches in the region [40].

Sediment cores were extracted from Garças Pond (GP) and Patos Pond (PP) (Fig. 1).

GP $\left(22^{\circ} 43^{\prime} 30.7^{\prime \prime} \mathrm{S}\right.$ and $\left.53^{\circ} 18^{\prime} 15.5^{\prime \prime} \mathrm{W}\right)$ is located on the right side of the Paraná River, to which it is permanently connected by a channel. The pond is approximately $150 \mathrm{~m}$ wide and $2.0 \mathrm{~km}$ long and has an area of $0.3 \mathrm{~km}^{2}$ and an average depth of $2.5 \mathrm{~m}$ [41]. PP $\left(22^{\circ} 49^{\prime} 30.64^{\prime \prime} \mathrm{S}\right.$ and $\left.53^{\circ} 33^{\prime} 12^{\prime \prime} \mathrm{W}\right)$ is located on the left bank of the Ivinhema River, to which it is permanently connected by a channel. This pond has an area of $1.14 \mathrm{~km}^{2}(0.65 \mathrm{~km}$ wide and $1.75 \mathrm{~km}$ long) and a depth between 2.8 and $4.8 \mathrm{~m}$ [42].

\section{Sampling}

The sediment cores were collected in October 2011. The cores were extracted from the deepest areas of the ponds because the fine particles (silt/clay) that adsorb the chemical elements are deposited in such areas. In the deepest area of each pond (depths of 3.5 and $4.5 \mathrm{~m}$ in GP and PP, respectively), a square meter was delineated from which six cores were collected. The samples were collected using polyvinyl chloride (PVC) hand corers that were $80 \mathrm{~mm}$ in diameter and $1.2 \mathrm{~m}$ long. Divers inserted the hand corers vertically into the sediment and then carefully extracted them. To minimize deformation of the cores, the bottom end was sealed with a stopper immediately after the hand corers were extracted.

The six sediment cores taken at the GP and PP were sliced at uniform intervals of 2.0 and $2.2 \mathrm{~cm}$, respectively, to obtain sub-samples. The sub-samples were placed in expanded polystyrene trays and dried at room temperature while protected from sunlight to avoid the loss of volatile chemical elements. After drying, the sub-samples were weighed.

\section{Chronological analysis}

The chronological analysis of the sediment cores using the ${ }^{210} \mathrm{~Pb}$ method was performed at the Laboratory of Environmental Radiometry of the Institute of Nuclear Energy Research.

The measurements of the radionuclides ${ }^{226} \mathrm{Ra}$ and ${ }^{210} \mathrm{~Pb}$ were used to determine the dates of deposition of each slice of the sediment cores collected from the ponds. The radionuclide activity concentration was measured every $4 \mathrm{~cm}$ from the first slice of each profile.

All the samples previously dried at $60{ }^{\circ} \mathrm{C}$ were passed through a $63-\mu \mathrm{m}$ sieve and digested in concentrated $\mathrm{HNO}_{3}$, $40 \% \mathrm{HF}$ and $30 \% \mathrm{H}_{2} \mathrm{O}_{2}$ for the radiochemical determination. The procedure included the initial precipitation of ${ }^{226} \mathrm{Ra}$ and ${ }^{210} \mathrm{~Pb}$ with $3 \mathrm{M} \mathrm{H} \mathrm{H}_{2} \mathrm{SO}_{4}$, dissolution of the 
precipitate with nitrilotriacetic acid at an alkaline $\mathrm{pH}$, precipitation of $\left.\mathrm{Ba}^{226}{ }^{\mathrm{Ra}}\right) \mathrm{SO}_{4}$ in a solution of ammonium sulfate and precipitation of ${ }^{210} \mathrm{PbCrO}_{4}$ in a solution of sodium chromate. The ${ }^{226} \mathrm{Ra}$ concentration was determined by gross alpha counting of the $\mathrm{Ba}\left({ }^{226} \mathrm{Ra}\right) \mathrm{SO}_{4}$ precipitate, and ${ }^{210} \mathrm{~Pb}$ was analyzed based on its decay product ${ }^{210} \mathrm{Bi}$ by measuring the gross beta activity of the ${ }^{210} \mathrm{PbCrO}_{4}$ precipitate. The chemical yields of both radionuclides were determined by a gravimetric analysis of the precipitate, and the ages were calculated using the constant rate supply (CRS) model [43]. We assumed constant accumulation of ${ }^{210} \mathrm{~Pb}$ because the results that we obtained for its concentration decreased exponentially, except for the results associated with flood events. The same occurred in previous work performed for us in the Brazilian wetland of Pantanal [29].

The method detection limits were $2.2 \pm 0.2 \mathrm{mBq} \mathrm{kg}^{-1}$ for ${ }^{226} \mathrm{Ra}$ and $4.9 \pm 0.4 \mathrm{mBq} \mathrm{kg}^{-1}$ for ${ }^{210} \mathrm{~Pb}$. For validation of the procedures, the reference materials Pacific Ocean Sediment 367 and Irish Sea Sediment 385, both from IAEA, were analyzed, and the results were in agreement with the certified values; the relative standard deviation and relative error for ${ }^{226} \mathrm{Ra}$ were 16.1 and $10.3 \%$, respectively, and the relative standard deviation and relative error for ${ }^{210} \mathrm{~Pb}$ were 13.5 and $1.1 \%$, respectively.

\section{Analysis for chemical elements}

The sediment samples were sieved through a PVC and nylon sieve with $63-\mu \mathrm{m}$ mesh, and the analyses for the chemical elements were performed on the silt/clay $(<63$ $\mu \mathrm{m}$ ) fraction as recommended by the World Health Organization [44].

The concentrations of calcium $(\mathrm{Ca})$, cadmium $(\mathrm{Cd})$, cobalt $(\mathrm{Co})$, chromium $(\mathrm{Cr})$, copper $(\mathrm{Cu})$, potassium $(\mathrm{K})$, magnesium $(\mathrm{Mg})$, manganese $(\mathrm{Mn})$, sodium $(\mathrm{Na})$, nickel $(\mathrm{Ni})$, lead $(\mathrm{Pb})$ and zinc $(\mathrm{Zn})$ were determined by flame atomic absorption spectrophotometry (FLAA). The opening of the samples and extraction of metals were conducted by wet digestion in accordance with USEPA method 3050B [45], which is indicated for the digestion of sediment and organic mud. The method detection limit for the analyses for chemical element concentrations was $1 \mathrm{ppm}$.

The analysis for mercury $(\mathrm{Hg})$ was conducted by AAS based on the Zeeman differential coupled with a pyrolysis reactor. The principle of this analysis is based on the thermal destruction of the sample followed by the measurement of $\mathrm{Hg}$ vapor. The method detection limit for the analyses of the solid samples was 5 ppb [46].

The certified reference materials IAEA 356 and IAEA 433 (marine sediment) were used to calculate the accuracy of the elemental analyses. Only analyses that displayed an accuracy between 93 and $107 \%$ for the element recovery relative to the reference samples were accepted.
Data analysis

The data were first analyzed using descriptive statistics for measures of central tendency. Subsequently, the concentration of each trace element over time was represented and evaluated using the statistical method of the Shewhart control chart for individual variables. In samplings of more than 25 points $(n \geq 25)$, the data can be considered as having a normal distribution for the application of the Shewhart control chart in accordance with the central limit theorem [47]. The upper control limit (UCL) and lower control limit (LCL) for each element were calculated using Eqs. (1) and (2), respectively [47].

$\mathrm{UCL}=\bar{X}+3 \times\left(\frac{\overline{\mathrm{MR}}}{d_{2}}\right)$

$\mathrm{LCL}=\bar{X}-3 \times\left(\frac{\overline{\mathrm{MR}}}{d_{2}}\right)$

Where, $\bar{X}$ represents the data mean; $\overline{\mathrm{MR}}$ represents the mean moving range of the data; and $d_{2}$ represents the constant used for the moving range of $n=2\left(d_{2}=1.128\right)$.

\section{Results}

Figure 2 shows the age dates of the slices from both cores (GP and PP), which were estimated using the ${ }^{210} \mathrm{~Pb}$ radioisotope geochronology method. The lowermost slice from the GP core, which was at a depth of $76 \mathrm{~cm}$, was deposited in 1912 (age of 99 years) and yielded a sedimentation rate of $7.7 \mathrm{~mm} \mathrm{year}^{-1}\left(2.66 \mathrm{~kg} \mathrm{~m}^{-2}\right.$ year $\left.^{-1}\right)$ in the deepest area of the lake. The lowermost slice of the PP core, which was at a depth of $84 \mathrm{~cm}$, was deposited in 1876 (age of 135 years) and yielded a sedimentation rate of $6 \mathrm{~mm}$ year $^{-1}$ (1.94 $\mathrm{kg} \mathrm{m}^{-2}$ year $^{-1}$ ) in the deepest area of the pond.

The minimum, mean and maximum concentrations (ppm) of the chemical elements in GP and PP are shown in Table 1 along with reference values for the Tietê River (RVTR) as proposed by Nascimento [48], global geological reference levels (GGRLs) compiled by Turekian and Wedepohl [49], and background levels that were estimated from the concentrations of metals in the fractions deposited before 1931. The background levels were estimated based on the mean and standard deviation of the concentrations of the elements deposited before 1931. The GP core contained four samples that had been deposited during this period, and the PP core contained 14. The $\mathrm{Cd}$ concentration in the GP cores was below the method detection limit (1 ppm).

The concentrations of the chemical elements in the GP and PP cores as a function of time are shown in Figs. 3 and 4 , respectively. At GP, the concentrations of $\mathrm{Ca}$ and 
Fig. 2 Formation date of the slices of sediment cores estimated by the ${ }^{210} \mathrm{~Pb}$ method. A: Garças Pond, B: Patos Pond
A

Date (y ears)

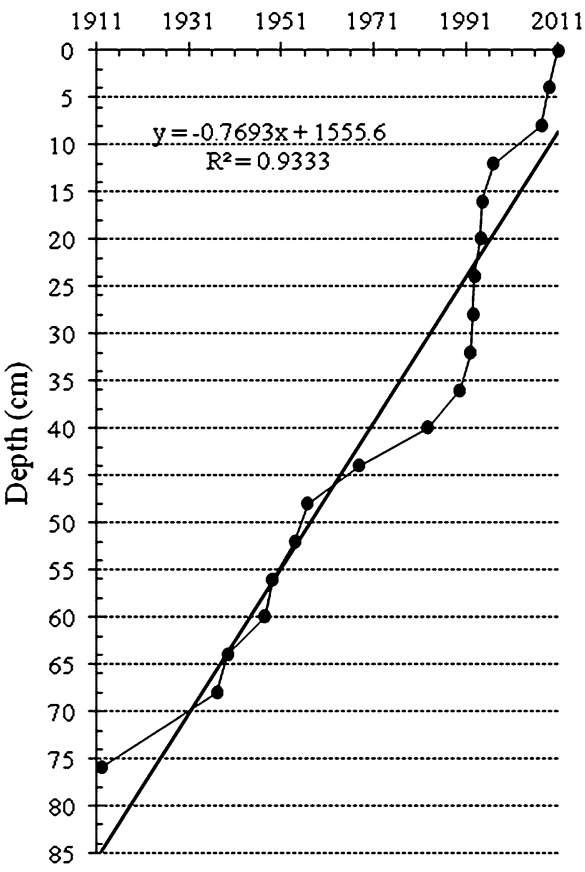

B

Date (years)

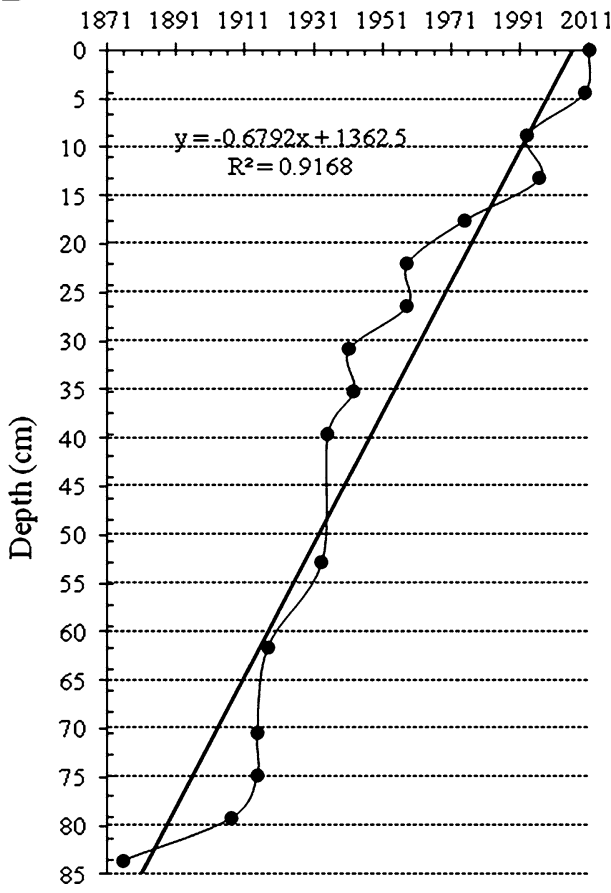

Table 1 Minimum, mean and maximum concentrations of the chemical elements (ppm) at the Patos Pond and Garças Pond

\begin{tabular}{|c|c|c|c|c|c|c|c|c|c|c|}
\hline \multirow[t]{2}{*}{ Elements } & \multicolumn{4}{|c|}{ Garças Pond } & \multicolumn{4}{|c|}{ Patos Pond } & \multirow[t]{2}{*}{ RVTR } & \multirow[t]{2}{*}{ GGRL } \\
\hline & Min & Mean & $\operatorname{Max}$ & Back & Min & Mean & Max & Back & & \\
\hline $\mathrm{Cd}$ & nd & nd & nd & nd & 0.64 & 1.18 & 1.72 & $1.40 \pm 0.20$ & $0.22 \pm 0.04$ & 0.3 \\
\hline Co & 19.70 & 22.72 & 33.45 & $27.60 \pm 5$ & 36.00 & 58.46 & 83.00 & $71.60 \pm 8.80$ & $22.00 \pm 4$ & 19 \\
\hline $\mathrm{Cr}$ & 24.13 & 31.27 & 51.51 & $36.30 \pm 3.2$ & 23.00 & 31.36 & 37.00 & $30.30 \pm 3.90$ & $76.00 \pm 64$ & 90 \\
\hline $\mathrm{Cu}$ & 37.82 & 51.81 & 79.12 & $49.60 \pm 2.8$ & 67.00 & 87.49 & 109.00 & $88.40 \pm 10.00$ & $52.00 \pm 44$ & 45 \\
\hline $\mathrm{Hg}$ & 0.036 & 0.055 & 0.067 & $0.05 \pm 0.01$ & 0.025 & 0.078 & 0.125 & $0.05 \pm 0.01$ & $0.11 \pm 0.04$ & 0.4 \\
\hline $\mathrm{Mn}$ & 254.00 & 325.60 & 528.00 & $475.00 \pm 77$ & 163.00 & 307.00 & 509.00 & $333.50 \pm 82.00$ & $*$ & 850 \\
\hline $\mathrm{Ni}$ & 12.00 & 20.44 & 31.00 & $15.00 \pm 2.5$ & 20.50 & 32.14 & 49.00 & $34.90 \pm 4.80$ & $39.00 \pm 17$ & 68 \\
\hline $\mathrm{Pb}$ & 17.00 & 22.58 & 39.00 & $23.40 \pm 2.5$ & 7.50 & 15.37 & 22.40 & $17.70 \pm 3.00$ & $42.00 \pm 15$ & 20 \\
\hline $\mathrm{Zn}$ & 57.00 & 63.56 & 89.00 & $62.70 \pm 3.4$ & 66.00 & 88.49 & 117.00 & $96.40 \pm 8.80$ & $90.00 \pm 22$ & 95 \\
\hline $\mathrm{Ca}$ & 3.71 & 19.18 & 48.75 & $19.20 \pm 9.5$ & 11.00 & 31.37 & 60.00 & $25.80 \pm 3.50$ & $*$ & 22,100 \\
\hline $\mathrm{K}$ & 2069.00 & 2517.00 & 3998.00 & $2647.00 \pm 199$ & 610.00 & 1063.00 & 1280.00 & $1083.00 \pm 177$ & $*$ & 26,600 \\
\hline $\mathrm{Mg}$ & 2818.00 & 3361.00 & 4268.00 & $3403.00 \pm 187$ & 1898.00 & 2475.00 & 3103.00 & $2332.00 \pm 272$ & $*$ & 15,000 \\
\hline $\mathrm{Na}$ & 195.00 & 353.00 & 747.00 & $249.00 \pm 9$ & 409.00 & 584.80 & 791.00 & $600.00 \pm 65$ & $*$ & 9600 \\
\hline
\end{tabular}

$R V T R$ reference values for the Tietê River ( $\mathrm{ppm}$ ) proposed by Nascimento [48] along with the standard deviation, GGRL global geological reference level (ppm) values compiled by Turekaian and Wedepohl [49]

* Nonexistent value, nd not detected, Min minimum; Max maximum; Back reference values were estimated from the mean and standard deviation of the concentrations of the elements sedimented before 1931

$\mathrm{Ni}$ increased over time, whereas the concentrations of Co, $\mathrm{Cr}$ and $\mathrm{Mn}$ decreased. At PP, the concentration of $\mathrm{Ca}$ and $\mathrm{Hg}$ increased over time, whereas the concentrations of $\mathrm{Cd}$, $\mathrm{Co}, \mathrm{Ni}$ and $\mathrm{Zn}$ decreased. The concentrations of other elements in both ponds showed no clear trend and remained close to the overall mean except for a few outliers.

\section{Discussion}

The sediment cores from both ponds (Fig. 2) were younger than the recommended age limit for analysis using the ${ }^{210} \mathrm{~Pb}$ radioisotope, which is a maximum of 150 years $[27,28]$. The cores from both ponds contained sediments dating from the Brazilian pre-industrial period before 1939. 

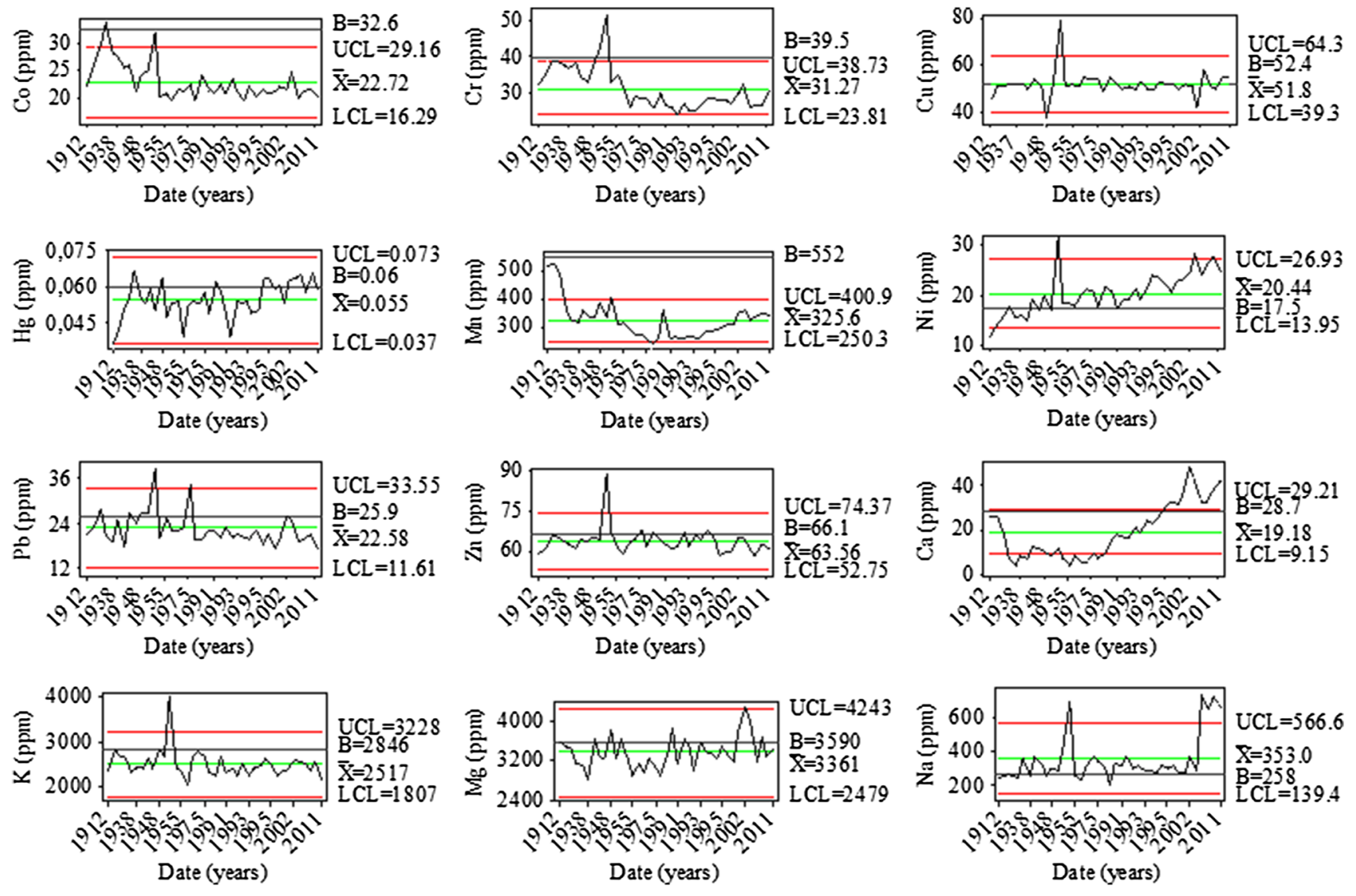

Fig. 3 Shewhart control chart for individual variables in the time series of the concentration of chemical elements at Garças Pond

The Brazilian industrial period started after the beginning of World War II because the industries in European countries had been destroyed and these countries were in need of imported manufactured goods from other countries such as Brazil. Thus, the concentrations in these samples can be considered to be background levels that predate anthropic activities [50]

The sedimentation rates obtained from the two ponds, i.e., $7.7 \mathrm{~mm}$ year $^{-1}$ at GP and $6 \mathrm{~mm}_{\text {year }}{ }^{-1}$ at PP (Fig. 2), are consistent with the study of Fávaro et al. [29], who reported a sedimentation rate of $6.1 \mathrm{~mm} \mathrm{year}^{-1}$ at Salina do Meio Pond $\left(0.126 \mathrm{~km}^{2}\right.$ area) in the Brazilian Pantanal, whose environment is similar to that of the Upper Paraná River floodplain. However, other studies in the Brazilian Pantanal yielded lower sedimentation rates. Godoy et al. [51] reported sedimentation rates of 4.1 and $3.7 \mathrm{~mm} \mathrm{year}^{-1}$ in two lakes of the Taquari River, and McGlue et al. [52] calculated a sedimentation rate of $2.4 \mathrm{~mm}$ year $^{-1}$ in Gaíva Lake (area of $80 \mathrm{~km}^{2}$ ). In general, sedimentation rates are lower in larger lakes because such lakes are less affected by particle entrainment from the margins, although this is only one of the factors that control the sedimentation rate.
High sedimentation rates can be detrimental to aquatic environments: higher sedimentation rates cause a higher contaminant load to enter the system along with the sediment. Consequently, chemical elements can become bioavailable through biogeochemical processes and can affect the aquatic biota [53].

The minimum and maximum concentrations of the chemical elements in the sediment from the GP and PP are presented in Table 1 along with the RVTR [48], GGRL [49] and the reference values estimated based on the fractions deposited before 1931 .

The concentrations of $\mathrm{Ca}, \mathrm{Cd}, \mathrm{Cr}, \mathrm{Hg}, \mathrm{K}, \mathrm{Mg}, \mathrm{Mn}, \mathrm{Na}$, $\mathrm{Ni}, \mathrm{Pb}$ and $\mathrm{Zn}$ in the GP sediment did not exceed the GGRL and RVTR reference values (Table 1). In the PP sediment, the concentrations of $\mathrm{Ca}, \mathrm{Cr}, \mathrm{Hg}, \mathrm{K}, \mathrm{Mg}, \mathrm{Mn}$, $\mathrm{Na}, \mathrm{Ni}$ and $\mathrm{Pb}$ did not exceed the reference values.

In the GP sediment, the Co concentrations exceeded the RVTR (22 $\pm 4 \mathrm{ppm})$ and GGRL (19 ppm) reference values (Table 1). The highest concentrations were recorded during the period of 1912-1954, and the lowest concentrations were recorded during the period of 1997-2011.

The concentrations of the remaining chemical elements ( $\mathrm{Ca}, \mathrm{Cd}, \mathrm{Co}, \mathrm{Cr}, \mathrm{Cu}, \mathrm{Hg}, \mathrm{K}, \mathrm{Mg}, \mathrm{Mn}, \mathrm{Na}, \mathrm{Ni}, \mathrm{Pb}$ and $\mathrm{Zn}$ ) at 

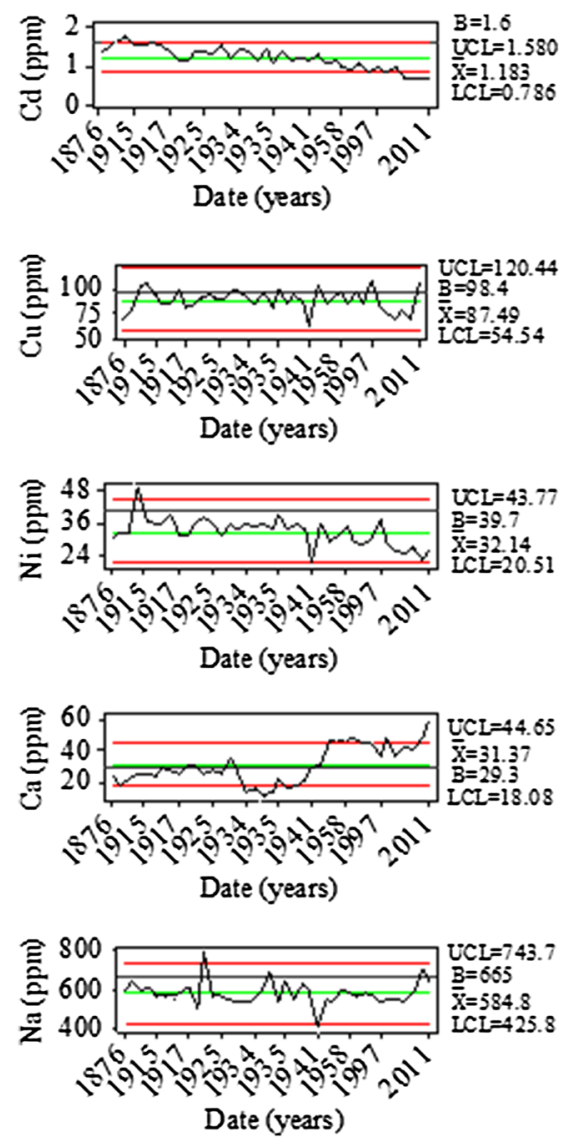
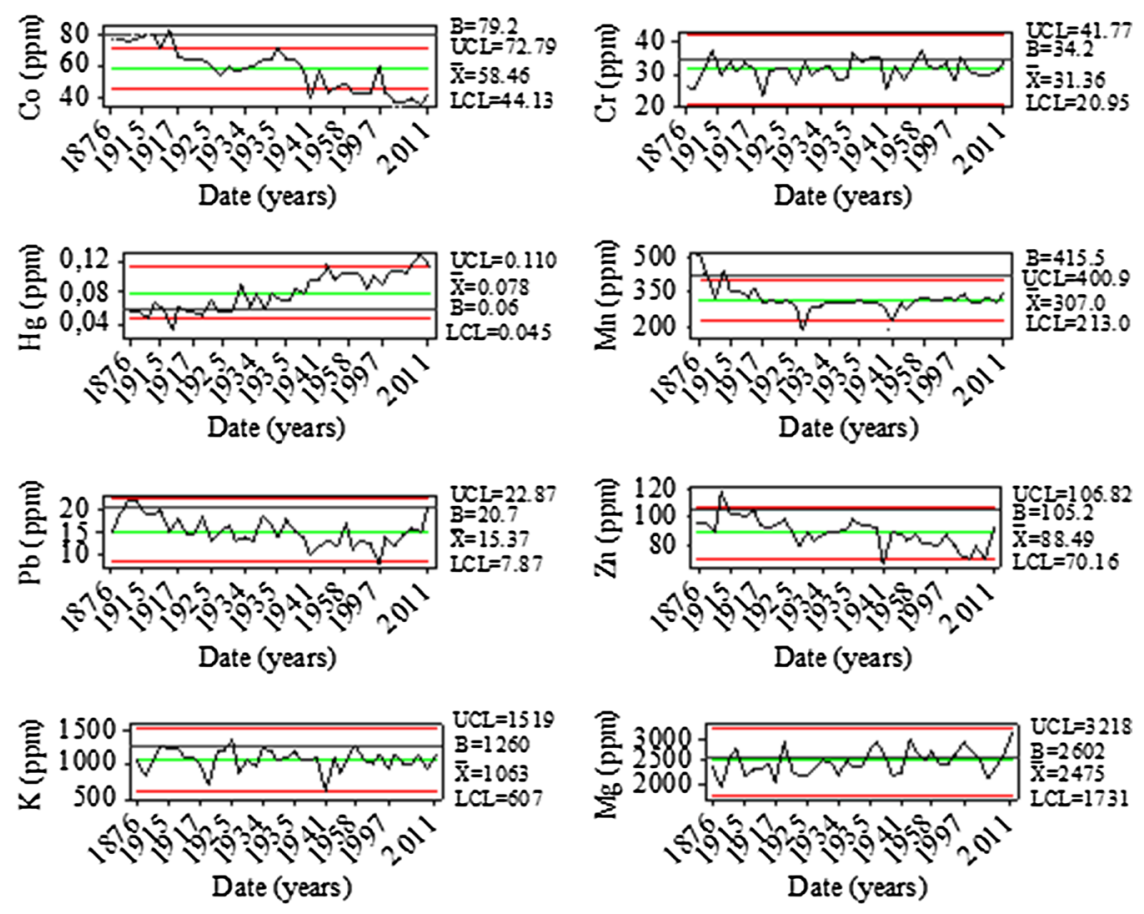

Fig. 4 Shewhart control chart for individual variables in the time series of the concentration of chemical elements at Patos Pond

GP did not exceed the RVTR reference value; however, the $\mathrm{Cu}$ and $\mathrm{Pb}$ concentrations exceeded the GGRL reference value (Table 1). The $\mathrm{Pb}$ concentrations were highly variable during the period of 1912-1980, and the variability decreased during the period of 1980-2011 and displayed a decreasing trend over time. The $\mathrm{Cu}$ concentrations fluctuated little around the overall mean except for a few outliers.

At PP, the Cd concentrations in the sediment exceeded the RVTR $(0.22 \mathrm{ppm})$ and GGRL $(0.30 \mathrm{ppm})$ reference values (Table 1). The highest $\mathrm{Cd}$ concentrations were recorded during the period of 1915-1917, and the lowest concentrations were recorded during the period of 1997-2011. The Co concentrations exceeded the RVTR $(22 \pm 4 \mathrm{ppm})$ and GGRL (19 ppm) reference values. The highest Co concentrations were recorded during the period of 1876-1917, and the lowest concentrations were recorded during the period of 1997-2011. The maximum concentration of $\mathrm{Zn}$ was recorded in 1915 (117 ppm), and this was the only sample in which the concentration exceeded the RVTR $(90 \pm 22 \mathrm{ppm})$ and GGRL (95 ppm) reference values. The $\mathrm{Cu}$ concentrations exceeded the GGRL reference value ( $45 \mathrm{ppm})$. The lowest $\mathrm{Cu}$ concentrations did not exceed the RVTR reference value $(52 \pm 44 \mathrm{ppm})$. The maximum concentrations of $\mathrm{Cd}, \mathrm{Co}$ and $\mathrm{Zn}$ were recorded during the period of 1876-1917. Anthropic activity did not cause these high concentrations because the drainage basin of the Ivinhema River was minimally populated at that time. The variation in $\mathrm{Cu}$ concentrations over time displayed a fluctuation around the mean without any clear trend, which indicates that anthropic factors did not affect the $\mathrm{Cu}$ concentrations of the PP sediment.

The fluctuations in the concentrations of the chemical elements in the sediments below both ponds were caused by flood pulses. When a flood pulse occurs, the amount of particulate matter entering the system increases. This sediment pulse is primarily a result of particle entrainment by runoff, which enriches the system with nutrients and contaminants [4]. Another factor that must be considered is the El Niño climate phenomenon, which causes increased rainfall in the drainage basin of the Paraná River (GP) $[23,24]$ and can increase the volume of the flood pulses.

More recently, the Ca concentrations at GP and PP were above the reference value, i.e., the mean concentration of $\mathrm{Ca}$ in the slices deposited before 1931 below both ponds (Figs. 3 and 4, respectively). The increase in Ca concentration over time at GP and PP is related to agriculture and 
urbanization. Ca is used in agriculture to reduce soil acidity, and approximately $80 \%$ of the drainage area of both ponds is used for agricultural activities [2]. Urbanization also contributed to the increase in the concentration of $\mathrm{Ca}$ because $\mathrm{Ca}$ is used in construction for the preparation of mortar. The population of Brazil has quadrupled during the previous 65 years, and in 1950 more than $60 \%$ of the population lived in rural areas. Brazil's rural population percentage decreased to $16 \%$ in 2010 , and the rural percentage in the drainage basin is even lower: $7 \%$ [54]. This trend was accompanied by an expansion of the construction industry and, consequently, the inappropriate disposal of construction waste.

More recently, the Ni concentrations at GP exceeded the reference value, i.e., the mean concentration of $\mathrm{Ni}$ in the slices deposited before 1931 at the pond (Fig. 3). The increase in the Ni concentration at GP is primarily associated with industrialization. $\mathrm{Ni}$ is primarily used in the manufacturing of stainless steel and other metal alloys and in casting. The largest city and largest industrial park (São Paulo) and the largest steel complex (Piracicaba) in Latin America are located in the drainage basin of the Paraná River [2]. Improper disposal of industrial waste, particularly waste from electroplating and porcelain enameling and from the production of paints, batteries and copper sulfate, explains the increase in the concentration of Ni [55].

Recently, the concentrations of $\mathrm{Hg}$ at PP were above the reference value, i.e., the mean pre-1931 concentration of $\mathrm{Hg}$ (Fig. 4). The concentration of $\mathrm{Hg}$ at PP displayed a gradual increase over time that is associated with the burning of sugarcane. According to Friedli et al. [56], $13 \%$ of global $\mathrm{Hg}$ emissions to the atmosphere are from the burning of biomass. In the Ivinhema River basin, 175,000 hectares are planted with sugarcane, which is equivalent to approximately $4 \%$ of the total basin area [57]. Sugarcane burning is the predominant technique to facilitate manual harvesting. Gold mining also contributes to the increased $\mathrm{Hg}$ concentrations. Although there are no reports of mining activity or illegal mines in the Ivinhema River basin, the $\mathrm{Hg}$ levels in the youngest samples $(0.12 \mathrm{ppm})$ were similar to those in sediment where there is gold mining activity, such as in the northern Brazilian Pantanal region (0.18 ppm) [58].

The concentrations of $\mathrm{Co}, \mathrm{Cr}$ and $\mathrm{Mn}$ in the GP sediment (Fig. 3) decreased over time due to oligotrophication of the Paraná Upper River floodplain in the study area. Oligotrophication is caused by the extensive installation of hydroelectric dams across the hydrographic area. Such dams sequester sediment along with nutrients and chemical elements [56]. Typically, the dams sequester only the coarse fraction of the sediment and allow the finer fraction, which is rich in contaminants, to flow downstream of the dam. However, because of the large number of dams in the Paraná River basin, a portion of the fine fraction is stored. In the study reach, the suspended sediment concentration decreased from $35 \mathrm{mg} \mathrm{L}^{-1}$ in the 1980 s to $0.5 \mathrm{mg} \mathrm{L}^{-1}$ after the raising of the last large dam in the basin (approximately $40 \mathrm{~km}$ upstream of the ponds under investigation) [20]. In addition, to supply the cities of São Paulo and Piracicaba, the two most industrialized areas of the basin, there are ten hydroelectric dams, which collectively hold approximately $600 \mathrm{~km}$ of backwater along the river. This backwater is sufficiently extensive to settle a portion of the fine fraction from the suspended sediment. Another factor that contributes to the decrease in the concentrations of the elements is an increase in the density of aquatic macrophytes, which adsorb nutrients and chemical elements from the medium. Mishra et al. [59] reported concentrations of trace elements that were 10-15 times greater in aquatic macrophytes than in the sediment. According to Thomaz et al. [60], submerged macrophytes were rarely observed in early studies of the floodplain but were more frequently observed after 1995 in lakes linked to the Upper Paraná River, such as GP.

The decline in the concentrations of $\mathrm{Cd}, \mathrm{Co}, \mathrm{Ni}$ and $\mathrm{Zn}$ in the PP sediment (Fig. 4) is associated with the increase in density of aquatic macrophytes in the environment. PP supports a diverse population of aquatic macrophytes, primarily floating macrophytes [61], which absorb nutrients and chemical elements from the medium. Furthermore, PP is connected to the Ivinhema River by a channel. The Ivinhema River's main channel may be shifting farther from the PP due to migration of the river meanders. Thus, it is possible that these elements are being deposited in the connection channel before reaching PP because they can be linked to the easily deposited particles. To confirm this hypothesis, it is necessary to perform a speciation analysis of these elements.

\section{Conclusions}

The primary factor regulating the supply of chemical elements in the Upper Paraná River floodplain is flood pulses, which may increase in size due to the El Niño-Southern Oscillation (ENSO).

The increase in agricultural area, urbanization and discharge of industrial effluents resulted in increases in the concentrations of calcium and nickel in the sediment of Garças Pond. Oligotrophication due to dams upstream of the floodplain and adsorption by aquatic macrophytes resulted in a decrease in the concentrations of cobalt, chromium and manganese in the Garças Pond sediment.

The burning of sugarcane, gold mining and increases in agricultural areas and urbanization resulted in increases in 
the concentrations of mercury and calcium in the Patos Pond sediment. The adsorption by aquatic macrophytes and the migration of river meanders resulted in the decrease in the concentrations of cadmium, cobalt, nickel and zinc in the PP sediments.

Acknowledgments We would like to thank the Brazilian Federal Agency for their scholarship grant under the program Support and Evaluation of Graduate Education (Coordenação de Aperfeiçoamento Pessoal de Nível Superior-CAPES), the 2nd SB/2nd SGB/5th GB of the Fire Department of the state of Parana and the Center for Research in Limnology, Ichthyology and Aquaculture (Núcleo de Pesquisas em Limnologia, Ictiologia e Aquicultura-NUPELIA) of the State University of Maringá (Universidade Estadual de Maringá-UEM) for providing divers, equipment and infrastructure for the collection of the sediment cores. We would also like to thank the Center of Mineral Technology (Centro de Tecnologia Mineral-CETEM) and, in particular, the Laboratory of Environmental Mercury Speciation (Laboratório de Especiação de Mercúrio Ambiental-LEMA) for performing the mercury analyses.

\section{References}

1. Agência Nacional das Águas (ANA) [National Water Agency] (2010) Atlas Brasil: abastecimento urbano de água [Atlas Brazil: urban water supply]. ANA, Brasília

2. Agência Nacional das Águas (ANA) [National Water Agency] (2012) Panorama da qualidade das águas superficiais do Brasil [Overview of the quality of surface waters in Brazil]. ANA, Brasília

3. Campos JB, Costa-Filho LV (1994) Proposta técnica de implantação da área de proteção ambiental do Arquipélago de ilha Grande [Technical proposal of implementation of the environmental protection area of the Ilha Grande Archipelago]. Curitiba, SEMA/IAP, p 54

4. Junk WJ, Bayley PB, Sparks RE (1989) Can Spec Publ Fish Aquat Sci 106:110-127

5. Neiff JJ (1990) Interciencia 15:424-441

6. Borges PAF, Train S (2009) Braz J Biol 69:501-516. doi:10. 1590/S1519-69842009000300018

7. Rodrigues LC, Train S, Bovo-Scomparin VM, Jati S (2009) Braz J Biol 69:501-516. doi:10.1590/S1519-69842009000300006

8. Pauleto GM, Velho LFM, Brao AFS, Tôha FAL, Bonecker CC (2009) Braz J Biol 69:517-527. doi:10.1590/S1519-6984200 9000300007

9. Algarte VM, Siqueira NS, Murakami EA, Rodrigues L (2009) Braz J Biol 69:609-616. doi:10.1590/S1519-69842009000 300015

10. Murakami E, Bicudo DC, Rodrigues L (2009) Braz J Biol 69: 459-468

11. Garcia DA, Benedito E, Takeda AM (2010) Braz Arch Biol Technol 53:1109-1118. doi:10.1590/S1516-89132010000500015

12. Mormul RP, Thomaz SM, Takeda AM, Behrend RD (2011) Biotropica 43:738-745. doi:10.1111/j.1744-7429.2011.00762.x

13. Cantanhêde G, Hahn NS, Gubiani EA, Fugi R (2008) Ecol Freshw Fish 17:47-53. doi:10.1111/j.1600-0633.2007.00258.x

14. Abujanra F, Agostinho AA, Hahn NS (2009) Brazil. Braz. J Biol 69:469-479. doi:10.1590/S1519-69842009000300003

15. Mormul RP, Thomaz SM, Higuti J, Martens K (2010) Hydrobiologia 644:185-193. doi:10.1007/s10750-010-0112-3

16. Ferreira FA, Mormul RP, Thomaz SM, Pott A, Pott VJ (2011) Rev Biol Trop 59:541-556
17. Mendonca LB, Lopes EV, Anjos L (2009) Braz J Biol 69:747-755. doi:10.1590/S1519-69842009000300028

18. Gimenes MR, Anjos L (2011) Braz Arch Biol Technol 54:415-427. doi:10.1590/S1516-89132011000200025

19. Martins DP, Bravard JP, Stevaux JC (2009) Lat Am J Sedimentol Basin Anal 16:111-118

20. Stevaux JC, Martins DP, Meuer M (2009) Geomorphology 110:1-20. doi:10.1016/j.geomorph.2009.03.015

21. Rocha PC (2010) Soc Nat 22:191-211. doi:10.1590/S198245132010000100014

22. Thomaz SM, Roberto MC, Bini LM (1997) In: Vazzoler AEAM, Agostinho AA, Hahn NS (eds) A planície de inundação do alto rio Paraná: aspectos físicos, químicos, biológicos e sócio-econômicos [The upper Paraná river floodplain: physical, biological and socioeconomic aspects]. Maringá, Eduem, p 73

23. Rao VB, Hada K (1990) Theor Appl Climatol 2:81-91. doi:10. 1007/BF00868215

24. Grimm A, Ferraz SET, Gomes J (1998) J Climate 11:2863-2880. doi:10.1175/1520-0442(1998)011<2863:PAISBA > 2.0.CO;2

25. Lenzi E, Luchese EB, Favero LOB, Dasilva AS (1997) Arq Biol Technol 40:760

26. Moraes LAF, Lenzi E, Luchese EB (1997) Environ Poll 98:123-127. doi:10.1016/S0269-7491(97)00101-2

27. He Q, Walling DE (1996) Earth Surf Process Landf 21:141-154. doi:10.1002/(SICI)1096-9837(199602)21:2<141:AID-ESP572> 3.0.CO;2-9

28. Terry JP, Kostaschuk RA, Garimella S (2006) J Environ Radioact 86:45-63. doi:10.1016/j.jenvrad.2005.07.004

29. Fávaro DIT, Damatto SR, Moreira EG, Mazzilli BP, Campagnoli F (2007) J Radioanal Nucl Chem 273:451-463. doi:10.1007/ s10967-007-6855-2

30. Trabelsi Y, Gharbi F, Ghali AE, Oueslati M, Samaali M, Abdelli W, Baccouche S, Tekaya MB, Benmansour M, Mabit L, M'Barek NB, Reguigui N, Abril JM (2012) J Soil Sediment 12:784-796. doi:10.1007/s11368-012-0496-y

31. Barsanti M, Delbono I, Schirone A, Langone L, Miserocchi S, Salvi A, Defanti R (2011) Sci Tot Envir 409:2959-2970. doi:10. 1016/j.scritotenv.2011.04.025

32. Basile S, Brai M, Rizzo S, Spanò M, Tranchina L (2011) J Soil Sedement 11:174-184. doi:10.1007/s11368-010-0314-3

33. Díaz-Asencio M, Alonso-Hernández CM, Bolanos-Álvarez Y, Gómez-Batista M, Pinto V, Morabito R, Hernández-Albernas JI, Eriksson M, Sanchez-Cabeza JÁ (2009) Mar Poll Bull 59:108-115. doi:10.1016/j.marpolbul.2009.02.010

34. Fávaro DIT, Damatto SR, Silva PSC, Riga AA, Sakamoto AY, Mazzilli BP (2006) J Radioanal Nucl Chem 269:719-726. doi:10. 1007/s10967-006-0292-5

35. Singer MB, Aalto R (2009) Earth Surf Process Landforms 34:291-304. doi:10.1002/esp. 1725

36. Aalto R, Nittrouer CA (2012) Philos Trans R Soc A 370:2040-2074. doi:10.1098/rsta.2011.0607

37. Singer BC, Aalto R, James A, Kilham NE, Higson JL, Ghoshal S (2013) PNAS 110:18436-18441. doi:10.1073/pnas.1302295110

38. Sringborn M, Singer MB, Dunne T (2011) Sci Total Environ 412-413:203-213. doi:10.1016/j.scitotenv.2011.10.004

39. Walling DE, Owens PN (2003) Hydrobiologia 494:83-91. doi:10. 1023/A:1025489526364

40. Campos JB, Souza MC (1997) In: Vazzoler AEAM, Agostinho AA, Hahn NS (eds) A planície de inundação do alto rio Paraná: aspectos físicos, biológicos e socioeconômicos [The upper Paraná River floodplain: physical, biological and socioeconomic aspects]. Eduem, Maringá, p 331

41. Rodrigues LC, Train S, Roberto MC, Pagioro TA (2002) Braz Arch Biol Technol 45:499-513. doi:10.1590/S1516-891320020006 00014 
42. Souza Filho EE, Stevaux JC (1997) In: Vazzoler AEAM, Agostinho AA, Hahn NS (eds) A planície de inundação do alto rio Paraná: aspectos físicos, biológicos e socioeconômicos [The upper Paraná river floodplain: physical, biological and socioeconomic aspects]. Eduem, Maringá, p 3

43. Damatto SR (2009) Dating of lacustrine and marine recent sediments using $210 \mathrm{~Pb}$ method: some Brazilian examples. In: International topical conference on $\mathrm{Po}$ and radioactive $\mathrm{Pb}$ isotopes-Sevilla-España, 26-28 Oct 2009, p 12-17

44. World Health Organization (WHO) (1982) Micropollutants in river sediments. World Health Organization, Copenhagen

45. United States Environmental Protection Agency (USEPA) (1996) Method 3050B. Acid digestion of sediments sludges and soils. USEPA, Washington, DC

46. Castilhos ZC, Rodrigues S, Rodrigues APC, Villas-Boas RC, Siegel S, Veiga MM, Beinhoff C (2006) Sci Tot Envir 368:320-325. doi:10.1016/j.scitotenv.2006.01.039

47. Montgomery DC (2009) Introdução ao controle estatístico da qualidade [Introduction to statistical quality control]. Translated by Ana Maria Lima de Farias, Vera Regina Lima de Farias e Flores; Technical revision Luiz da Costa Laurencel. 4th ed., reimpr.- LTC, Rio de Janeiro

48. Nascimento MRL (2003) Proposição de valores de referência para concentração de metais e metaloides em sedimentos limnicos e fluviais da bacia hidrográfica do rio Tietê, SP [Proposed reference values for concentrations of metals and metalloids in limnic and fluvial sediments from the Tietê River, SP]. Universidade Federal de São Carlos, Thesis

49. Turekian KK, Wedepohl KH (1961) Sci Total Environ 368:320-325

50. Förster U, Ahlf W, Calmano W (1993) Water Sci Technol 28:307_ 316
51. Godoy JM, Padovani CR, Guimarães JRD, Pereira JCA, Vieira LM, Carvalho ZL, Galdino S (2002) J Braz Chem Soc 13:71-77. doi:10.1590/S0103-50532002000100011

52. McGlue MM, Silva A, Corradini FA, Zani H, Trees MA, Ellis GS, Parolin M, Swarzenski PW, Cohen AS, Assine ML (2011) J Paleolmnol 46:273-289. doi:10.1007/s10933-011-9538-5

53. Cantwell MG, Burgess RM, Kester DR (2002) Environ Sci Technol 36:5328-5334. doi:10.1021/es0115058

54. IBGE. Sistema IBGE de Recuperação Automática [IBGE's Automatic Recovery System]. http://www.sidra.ibge.gov.br/bda/ tabela/listabl.asp?z=cd\&o=2\&i=P\&c=1286 Accessed 4 July 2013

55. Farooq U, Kozinski JA, Khan MA, Athar M (2010) Bioresour Technol 101:5043-5053. doi:10.1016/j.biortech.2010.02.030

56. Friedli HR, Radke LF, Lu JY, Banic CM, Leaitch WR, MacPherson JI (2003) Atmos Environ 37:253-267. doi:10.1016/ S1352-2310(02)00819-1

57. IBGE. Censo Agropecuário 2006: Resultados preliminares [2006 Agricultural Census: Preliminary results] IBGE. 2007. http:// www.ibge.gov.br/home/estatistica/economia/agropecuaria/censoa gro/2006/default.shtm. Accessed 4 July 2013

58. Tümpling W, Wilken RD, Einax J (1995) J Geochem Explor 52:127-134. doi:10.1016/0375-6742(94)00040-I

59. Mishra VK, Upadhyaya AR, Pandey SK, Tripathi BD (2008) Environ Monit Assess 141:49-58. doi:10.1007/s10661-007-9877-x

60. Thomaz SM, Bini LM, Pagioro TA, Murphy KJ, Santos AM, Souza DC (2004) In: Thomaz SM, Agostinho AA, Hahn NS (eds) The upper Paraná River and its floodplain: physical aspects, ecology and conservation. Backhuys Publishers, Leiden, p 331

61. Thomaz SM, Carvalho P, Padial AA, Kobayashi JT (2009) Braz J Biol 69:617-625. doi:10.1590/s1519-69842009000300016 